\title{
Konsep Jihad dalam Tafsir Al-Maraghi (Studi Tafsir Tematik Tentang Jihad dalam QS. At-Taubah)
}

\author{
Risqo Faridatul Ulya, Hafizzullah \\ Universitas Islam Negeri Sunan Kalijaga Yogyakarta \\ Institut Agama Islam Negeri Batu Sangkar \\ risqoulya96@gmail.com
}

\begin{abstract}
This article discusses the Concept of Jihad in Tafsir al-Maragi (Thematic Study of Jihad in QS. At-Taubah). The purpose of this research is to reveal: The concept of jihad in surah at-Taubah in the al-Maragi interpretation, and the contextualization of contemporary jihad. This research is a library research using descriptive analysis method. The data sources of this study consisted of primary data sources, namely Tafsir al-Maragi, while secondary data sources, namely the Kitab al-Mu'jam al-Mufahrasy li al-Fazdil Quran Karim, encyclopedias, journals and literature relevant to jihad. Data collection techniques, researchers used document studies, which were analyzed using steps in the thematic method. The conclusion of this research is: the concept offered by the interpretation of al-Maragi in surah at-Taubah is to mobilize all the strength, ability, and ability to fight against enemies, be it infidels, polytheists or hypocrites, by sacrificing the totality of their assets and themselves. In the sense that there is a certain way described by Abmad Mustafa al-Maragi regarding his interpretation, namely that it is attempted orally first, if they do more than that then jihad may be done by hand. With the aim of jihad or striving in the way of Allah, which is a way to maintain the existence of the people and the height of their sentences, clean them from weak faith and neglect of Islamic rights, uphold a balance of justice, uphold the righteous and have a higher degree of virtue, glory, high position in the dignity of virtue and perfection, greater rewards, enjoy the pleasures of the world and Allah promises that people who jihad will get various eternal happiness in the hereafter. Meanwhile, the contextualization of jihad today is jihad with the media, jihad with economics, jih ad with knowledge and jihad with oneself.
\end{abstract}

Keywords: Tafsir Al-Maraghi, Concept of Jihad, Contextualization of Jihad

Abstrak. Artikel ini membahas tentang Konsep Jihad dalam Tafsir al-Maragi (Studi Tafsir Tematik tentang Jihad dalam QS. At-Taubah). Tujuan penelitian ini adalah untuk mengungkap: Konsep jihad dalam surah at-Taubah pada tafsir al-Maragi, dan Kontekstualisasi jihad masa kini. Penelitian ini termasuk penelitian kepustakaan (library research) dengan metode analisis-deskriptif. Sumber data penelitian ini terdiri dari sumber data primer, yaitu Tafsir al-Maragi, sedangkan sumber data sekunder, yaitu Kitab al-Mu'jam al-Mufahrasy li al-Fazdil Quran Karim, 
ensiklopedia, jurnal dan literatur yang relevan dengan jihad. Teknik pengumpulan data, peneliti menggunakan studi dokumen, yang dianalisis menggunakan langkahlangkah dalam metode tematik. Kesimpulan penelitian ini adalah: konsep yang ditawarkan tafsir al-Maragi dalam surah at-Taubah ialah menggerahkan segenap kekuatan, kemampuan, dan kesanggupan untuk melawan musuh baik itu orang kafir, musyrik maupun munafik, dengan mengorbankan secara totalitas harta dan diri mereka. Dalam artian ada cara tertentu yang dipaparkan oleh Ahmad Musthafa al-Maragi tentang penafsirannya yakni diusahakan dengan lisan terlebih dahulu, apabila mereka melakukan lebih dari itu maka sebaliknya jihad boleh dengan tangan. Dengan tujuan berjihad atau berjuang di jalan Allah yaitu merupakan jalan untuk memelihara keberadaan umat dan ketinggian kalimatnya, membersihkan mereka dari keimanan yang lemah dan kelalaian terhadap hak-hak Islam, menegakkan neraca keadilan, menegakkan yang haq serta mempunyai keutamaan yang lebih agung derajatnya, kemuliaannya, tinggi kedudukannya dalam martabat keutamaan dan kesempurnaan, lebih besar pahalanya, menikmati kesenangan di dunia serta Allah menjanjikan bahwa orang berjihad akan memperoleh berbagai kebahagiaan abadi di akhirat kelak. Sedangkan kontekstualisasi jihad masa kini ialah jihad dengan media, jihad dengan ekonomi, jihad dengan ilmu dan jihad dengan diri.

Kata kunci: Tafsir Al-Maraghi, Konsep Jihad, Kontekstualisasi Jihad

\section{PENDAHULUAN}

Era sekarang ini Islam banyak diperdebatkan di berbagai kalangan baik kalangan Islam maupun non-Muslim. Sebagian orang beranggapan agama Islam ini, mencetak fanatisme yang sangat berlebihan di atas rata-rata, pembawa teror dan bahkan mengajarkan kekerasan. Sebagian lain menganggap bahwa Islam adalah agama yang tentram, damai dan membawa ketenangan batin baik jasmani maupun rohani.

Kemudian dilihat dari fenomena yang ada di masyarakat semakin menajam, mereka banyak memahami tentang jihad itu beragam. Tetapi, sebagaian besar mengatakan bahwa jihad itu lebih identik dengan peperangan, pengeboman (bom bunuh diri), dan pembunuhan. Faktanya seperti, pengeboman di Bali 1 dan 2 malam tanggal 12 Oktober 2002, terjadinya ledakan bom di Paddy's Cafe dan Sari Club di kawasan Legian, Kuta, Bali. Dengan merenggut nyawa kurang lebih 202 jiwa, 164 warga asing dari 21 negara, 38 warga Indonesia (Simanjuntak, 2016:118). 
Pandangan lebih ekstrim dikemukakan oleh Mahmud Thaha, pemikir Muslim berkebangsaan Sudan. Setelah menelusuri sejumlah ayat yang berbicara tentang term jihad, ia sampai pada kesimpulan bahwa jihad bersifat fisik bermakna perang, sebagaimana yang dipahami secara salah oleh sebagian besar umat Islam pada umumnya itu bukanlah merupakan ajran dasar Islam. Kenyataan akan mainstream pemaknaan tunggal terhadap jihad yang diartikan sebagai perang diakui oleh Said Ramdhun al-Buthi. Padahal, menurut al-Buthi apabila jihad diartikan dengan perang, maka ajaran jihad akan kehilangan makna dan bentuk variasinya (Junaedi, 2016: 154).

Aplikasi dan pemahaman yang semacam inilah sangat berpengaruh dalam kehidupan sosial sehingga tidak terlepas dari kesenjangan masyarakat antar agama. Sehingga orang yang mempunyai pemandangan tentang jihad adalah perang mereka lebih arogan dalam bertindak dan terkadang objek mereka yaitu non-muslim mereka yang sedikit di antara kelompok Islam yang ada kesenjangan maka mereka memilih untuk berjihad. Islam mengajarkan toleransi antar agama agar terciptanya kerukunan antar sesama dan kedamaian itulah syari'at agama Islam sebenarnya. Dengan hal ini tidak menutup kemungkinan menimbulkan kesenjangan yang ada di masyarakat baik dikalangan non-muslim maupun muslim sendiri. Padahal dalam Islam hal semacam ini ditolak.

Dalam penelitian ini peneliti menggunakan penafsiran Ahmad Musthafa al-Maragi dalam kitab tafsir al-Maragi yang mana beliau menerapkan metode gabungan antara metode tafsir bi al-ma'tsur dan metode bi al- ma'qul dengan corak penafsiran al-Adabi ijtima'I (Sayadi, 2011: 98). Selanjutnya mengenai pembatasan penelitian yakni dalam surah at-Taubah dikarenakan surah ini berisi tentang peperangan dan pengkhianatan (Lajenah, 2015: 508) kaum munafik dan kafir kepada umat Islam. Dengan tujuan peneliti mencoba untuk mengungkap: Konsep jihad dalam surah at-Taubah 
dalam tafsir al-Maragi, dan Relevansi jihad dengan konteks masa kini menurut tafsir al-Maragi.

Oleh karena itu perlunya memahami konsep jihad itu dengan baik dari pemahaman dan pengertian ayat-ayat dalam Alquran beserta penafsiran Ahmah Musthafa Al-Maragi dalam membicarakan tema jihad. Berangkat dari titik inilah mengapa tema jihad ini sangat menarik untuk dikaji, bahwasanya jihad ini berlaku untuk setiap muslim demi menegakkan kalimattullah dan membela agama Allah.

Penelitian ini merupakan penelitian kepustakaan dengan metode analisis-deskriptif. Sumber data penelitian ini terdiri dari sumber data primer, yaitu Tafsir al-Maragi, dan sumber data sekunder, yaitu ensiklopedia, Kitab alMu'jam al-Mufahrasy li al-Fazdil Quran Karim, jurnal serta literatur yang relevan dengan jihad. Teknik pengumpulan data, peneliti menggunakan studi dokumen, dan dianalisis menggunakan langkah-langkah metode tematik. Peneliti menggunakan beberapa riset tematik yaitu tematik surah, istilah dan konseptual. Penelitian ini tidak termasuk secara keseluruhan tematik surah dikarenakan tematik surah merupakan kesatuan secara utuh tetapi digunakan oleh peneliti dalam pembatasan pada surah at-Taubah saja. Tematik istilah juga digunakan oleh peneliti sesuai dengan namanya karena mengacu pada istilah tertentu tetapi tidak secara keseluruhan karena tidak mencakup kata jihad di surah lainnya. Demikian juga tematik konseptual mengambil konsepkonsep yang terdapat dalam surah at-Taubah. Tetapi tetap mengacu pada riset tematik surah dikarenakan pembatasan dalam penelitian dengan metode mandbu'i.

\section{HASIL DAN PEMBAHASAN}

\section{Pengertian Jihad}

Menurut etimologi, jihad memiiki dua makna, yaitu sukar (المشقة), dari kata jahd, dan kemampuan (الطاقة), dari kata jubd (Nasution dan Bakti, 2009: 303). Term jihad secara etimologi dari kata aljuhdu ialah menggerahkan 
seluruh kemampuan dan tenaga (devoting all ability and efforts). Tetapi apabila kata dasarnya al-jahdu, bermakna melakukan pekerjaan yang berlebihan (doing the job superfluously). Kata ini mengandung tiga derivasi yakni jihad, mujahadah dan ijtihad makna ini seringkali terpisah-pisah. Jihad diartikan sebagai perang fisik. Mujahadah diartikan bersungguh-sungguh dalam jiwa. Makna ini sering digunakan para sufi diproses dalam pemurnian hidup mereka sementara ijtihad didefinisikan sebagai memaksimalkan pikiran dengan sungguhsungguh menegakkan hukum. (Ramlan dkk, 2016: 35)

Sedangkan terminologi Islam volume 1, kata jihad bermakna berjuang dengan bersungguh-sungguh mengerahkan segenap potensi yang dimiliki dalam mencapai tujuannya, khususnya dalam menghadapi musuh, menegakkan kebenaran, dan keluhuran (Shihab, 2007: 395).

Menurut Ragib Asfahani menjelaskan bahwa jihad dan mujahadah secara kebahasaan berarti mengerahkan segenap kemampuan untuk mempertahankan diri dari musuh. Ia membagi jihad ke dalam tiga jenis yaitu, jihad kepada musuh yang tampak, jihad kepada setan, dan jihad terhadap diri sendiri (Departemen Agama RI, 2008: 137).

Dengan demikian, beberapa pendapat di atas mengenai tentang jihad. Pendapat tersebut di atas itu tidak bertentangan satu sama lain, melainkan para ulama saling melengkapi dengan tujuan yang sama dalam memaknai arti jihad itu sendiri.

\section{Perspektif al-Qur'an tentang Jihad}

Peneliti menemukan 41 ayat jihad dengan berbagai derivasinya, diantaranya: Surah al-Baqarah [2]: 218, Surah al-Imran [3]: 142, Surah an-Nisa [4]: 95, Surah al-Maidah [5]: 35,53,54, Surah al-An'am [6]: 109, Surah al-Anfal [8]: 72,74,75, Surah at-Taubah [9]: 16, 19, 20, 24, 41, 44, 73, 79, 81, 86, 88, Surah an-Nahl [16]: 38,110, Surah al-Hajj [22]: 78, Surah an-Nur [24]: 53, Surah al-Furqan [25]: 52, Surah al-Ankabut [29]: 6, 8, 69, Surah al-Luqman [31]: 15, Surah Fathir [35]: 42, Surah Muhammad [47]: 31, Surah Hujurat [49]: 
15, Surah al-Mumtahanah [60]: 1, Surah as-Shaff [61]: 11, dan Surah atTahrim [66]: 9 (Baqi, 1981: 183).

Mengenai fokus kajian tentang jihad dalam surah at-Taubah, karena peneliti melakukan pengecekan di kitab Mujam mufabras fi ₹bilalil quran bahwa dalam ayat ini yang paling banyak membahas tentang jihad dalam Alquran, di dalam surah inipun sudah terdapat gambaran konsep jihad yang dilengkapi dengan definisi jihad, objek jihad, media jihad, cara berjihad, macam-macam jihad, tujuan jihad dan keutamaan jihad serta keterbatasan referensi pada saat ini dalam menelusuri konsep jihad secara menyeluruh. Maka dari itu peneliti hanya mengfokuskan kajian di surah at-Taubah saja.

\section{Istilah-Istilah Dasar Jihad}

Kata jihad merupakan bentuk masdar. Berasal dari kata jahada-yujabidujihad-mujahadah. Secara epistemologi menggerahkan segenap kemampuan dan kekuatan. Umumnya, jihad diartikan perang menolong agama dan memelihara kehormatan umat. Namun, Alquran dan sunnah menggunakan kata itu dalam makna yang lebih meluas bukan hanya sekedar perang.

Qital adalah bentuk terakhir jihad, yakni perang menggunakan pedang. Makna umumnya dari kata jihad, meskipun keduanya tidak mempunyai persamaan etimologi. Qital berasal dari qatala-yuqatilu-qital-muqatala. Qital serangkai dengan kata qatl yang artinya membunuh, sementara jihad dari jahada berarti beban berat. Kata qital beragam bentuk derivasinya disebutkan dalam Alquran sebanyak 67 kali. Kata ini tidak mengandung nilai apapun dalam Islam apabila tidak dilakukan di jalan Allah.

Al-harb adalah bentuk masdar 4 kali dan terdapat 2 bentuk lainnya (Irawan, 2014: 69). Penggerahan seluruh kekuatan, senjata, alat untuk melawan kelompok lain. Perbedaan antara jihad dan al-harb adalah jihad lebih cenderung kepengertian agama, mempunyai tujuan, motif, cara, aturan dan etika sedangkan al-harb hanya lebih kepada kamus duniawi. 
Kekerasan (al-Unf) artinya keras dan kejam, antonimnya lembut. Kata ini tidak terdapat dalam Alquran. Dalam hadis Nabi disebutkan sebagai sikap yang tidak baik dan harus ditinggalkan. Kata ini menjadi lumrah dan dicondongkan kepada umat Islam disebabkan ulah kelompok orang Islam yang memilih menggunakan jalan kekerasan dalam melakukan perubahan tubuh umat Islam. Kelompok semacam ini bukan perwakilan mayoritas umat Islam yang mengecam aksi kekerasan.Namun, sangat diherankan ketika kekerasan dianggap bagian dari Islam dengan alasan Islam mengajarkan jihad.

Teror (al-Irhab) berasal dari bentuk masdar Arbab-Yurbibu-irbab, artinya menakut-nakuti. Bentuk tsulatsi, rahaba artinya takut, antonimnya amina bermakna aman. Jadi al-irbab ialah mewujudkan situasi ketakutan di tengah masyarakat sebagai akibat dari sebuah aksi militer. Pada dasarnya menakutnakuti itu dilarang Nabi. Perkara semacam ini diperbolehkan apabila mempunyai tujuan yang dibenarkan dengan cara benar (al-Qardhawi, 2011: 29-35).

Adanya istilah-istilah dasar jihad ini bisa membuka pemikiran oranagorang bahwa makna jihad itu luas. Dan jangan menjadikan jihad itu sebagai prioritas perang. Apabila ingin bergerak ke jenjang jibad fisabilillah maka kita sebagai umat islam harus membekali diri dengan niat, cara dan tujuan yang baik.

\section{Fungsi Jihad}

Adapun aspek fungsi jihad sebagai berikut: Aspek ibadah: dalam Alquran menyatakan bahwa jihad dapat berperan secara fungsional dalam menggapai kesempurnaan diri. Allah berfirman Q.S. at-Taubah/9:19. Aspek dakwah: jihad merupakan sebagai kekuatan dakwah yang bertujuan menstimulasi dan membangun semangat muslim dalam menyampaikan dakwahnya. Aspek politik dan militer: adanya syarat jihad yang berkaitan dengan perang dan perintah agar menyiapkan kekuatan militer, umat Islam dapat menggetirkan invasi lawan yang akan mereka hadapi, bertujuan agar 
umat terhindar dari ancaman dan penganiayaan dan aspek spiritual keagamaan: jihad salah satu bentuk ajaran agama dalam meningkatkan dan menyempurnakan iman seseorang. Maka Alquran menawarkan untuk meningkatkan keimanan dengan cara melakukan jihad (Rohimin, 2006: 111122).

\section{Objek Jihad}

Menurut M. Quraish, susunan redaksi kata yang tidak meyebutkan objeknya itu bersifat universal dan merangkum segala hal yang dapat dijangkau oleh kata tersebut. Atas pemahaman ini,kata jahada dan derivasinya dalam Alquran bermakna memaksa, memperoleh, sanggup dan bersungguhsungguh, dan tidak menyebutkan objek secara spesifik, maka objeknya mencakupi semua yang dapat dijangkau oleh kata. Penyebutan objek jihad dalam Alquran hanya diungkapkan 5 ayat, yaitu: Q.S. at-Taubah/9: 36 dan 73, Q.S. al-Hujurat/49: 9, Q.S. at-Tahrim/66: 9, Q.S. an-Nisa'/4: 76. Adapun objeknya ialah: orang-orang kafir (Rohimin, 2006: 129), orang munafik (Nurkholis, 2007: 49),orang musyrik (Shihab, 2007: 664), hawa nafsu, setan, dan al-Bighat (Rohimin, 2006: 134-142).

\section{Bentuk-Bentuk Jihad}

Bentuk-bentuk jihad dalam Alquran adalah sebagai berikut: Jihad dengan Alquran: Jihad dalam bentuk ini merupakan bentuk jihad yang pertama kali dilakukan pada periode Mekkah. Berhubungan dengan ayat QS. al-Furqan/25:52, para ahli tafsir berbeda pemahaman dalam menemukan bentuk jihad pada ayat di atas. Perbedaan ini ditemukan pada kata bibi dalam ayat. Menurut ar-Razi perbedaannya sebagai berikut: a)bekerja keras, dan berdoa, b) berperang c) bekerja keras, berdoa, dan berperang. Tiga pemahaman di atas, Ar-Razi lebih cenderung pada pemahaman pertama, dikarenakan ayat itu turun pada periode Mekah. Tidak tepat jika ayat jihad dipahami dengan perang, karena perang berlaku di periode Madinah setelah berhijrah (Rohimin, 2006: 143). Jihad dengan harta: perintah jihad dengan 
harta dalam Alquran tidaklah dijelaskan spesifik bentuk kongkretnya. Berjihad dengan harta dibagi menjadi dua pengertian, yakni umum (memberikan hartanya secara keseluruhan dengan tujuan agar membantu umat dan mengantarkan kepada keridhaan Allah SWT) dan khusus (mengkonstribusikan hartanya untuk menyokong bidang-bidang tertentu yang berkaitan dengan jihad militer, dan memberi tunjangan ekonomi di keluarga dan kerabat pada mujahidin) (Takruri, 2007: 1). Jihad dengan jiwa raga: pengertian jiwa tidak selalu diidentikan dengan perang, namun maknanya luas dan meliputi seluruh gerakan manusia serta kesanggupan fisiknya.

Adapun bentuk-bentuk jihad jiwa antara lain: Jihad Jiwa dengan Tangan ( $Y a d)$ dibagi menjadi 3: a) Jihad tangan degan angkatan perang: kaum muslim diharuskan membuat kelompok khusus angkatan perang yang mempunyai kualitas personil baik dalam akidah, fisik, dan melakukan pelatihan kemiliteran. b). Jihad tangan dengan kekuasaan: pemerintah diharuskan memiliki kekuasaan, menjalankan undang-undang,memegang kedaulatan dalam menentukan program kerja,bebas dari segala bentuk penekanan pemerintah lain dalam segala aspek. c). Jihad tangan dengan kekuataannya: jihadnya untuk menegakkan al-haq dan melenyapkan kebatilan dengan kekuatannya. Adapun yang perlu diperhatikan dalam melaksanakan jihad dengan tangan: (1) mendiskusi dengan baik tentang tempat maksiat yang dibuat oleh si pelaku. Maka tidak perlu melakukan jihad tangan dengan kekuatan. (2) Tindakan yang dilakukan ke si pelaku tersebut harus sewajarnya saja. Jihad jiwa dengan lisan: tidak sekedar mengingatkan kepada orang yang lengah mengeluarkan perkataan saja. Namun, diartikan sebagai usaha untuk menyampaikan ajaran Islam secara murni. Jihad jiwa dengan lisan ada 3 bagian: 1). Jihad lisan dengan perkataan: perintah Allah kepada Rasul-Nya dalam menyampaikan risalah kepada umat. 2) Jihad lisan dan tulisan: kemampuan seorang muslim dalam menulis. 3) Jihad lisan dengan teknologi 
informasi modern untuk memudahkan kaum umat dalam memanfaatkan sarana teknologi dalam menyebarankan ajaran Islam agar menjadi efektif. Dan jihad jiwa dengan hati: jihad untuk seseorang yang tidak mampu melakukan kewajiban jihadnya dengan menggunakan tangan atau lisan dengan alasan syara' (Almascaty, 2001: 86- 176).

\section{Riwayat Singkat Hidup Ahmad Mustafa al-Maragi}

Nama lengkapnya adalah al-Fadilat al-Ustadz al-Kabir Ahmad Mustafa bin Muhammad bin Abdul al-Mun'im al-Qadi' al-Maragi. Ia dilahirkan pada tahun $1300 \mathrm{H}$ (1883 M) terletak di perkampungan Mesir yang disebut al-Maraga, perkampungan ini menjadi tempat dinisbatkannya nama beliau, yang populer dengan sebutan Syekh al-Maragi, di wilayah pemerintahan Jurja bagian dari provinsi Suhaj sekitar $700 \mathrm{~km}$ arah selatan Kairo Mesir (Sayadi, 2011: 33). Sejak kecil al-Maragi sudah menunjukkan kecerdasannya dan memiliki pribadi yang agung (Imzi, 2013: 169).

Di lembaga pendidikan Universitas al-Azhar beliau mengkaji berbagai bidang ilmu seperti bahasa Arab, balaghah, tafsir, hadis, fiqh dan falak. Pada tahun 1909, ia menyelesaikan kuliahnya dan diberikan amanat sebagai staf pengajar di perguruan tinggi dengan mengampuh mata kuliah Syariat Islamiah dan beberapa lembaga pendidikan lainnya. Kemudian menurut informasi yang didapat bahwa Syekh al-Maragi diangkat menjadi direktur sekolah guru Fayum. Pada tahun 1916, ia menjadi dosen sekaligus guru besar di Fakultas Gurdum di Khurtum Sudan dengan mengampuh mata kuliah Bahasa Arab.

Beliau berguru kepada Syekh Muhammad Abduh, Syekh Muhammd Hasan al-Adawi, Syekh Muhammad Bahis al-Muti' dan Syekh Muhammad Rifa'i al-Fayumi. Inilah beberapa guru besar Musthafa al-Maraghi yang ikut serta dalam membentuk intelektualitas dalam berbagai kelimuan (Ghofur, 2013: 98). 
Pada tahun 1920 iapun kembali ke Kairo dan diangkat sebagai dosen Bahasa Arab dan Syari'ah Islamiyah di Perguruan Tinggi Dar al-Ulum sampai tahun 1940. Di Samping itu, ia juga mengajar Balaghah dan Sejarah Kebudayaan Islam di Fakultas Adab di Universitas Al-Azhar. Di antara murid-muridnya adalah Dr. Fathi Ismail di Mesir, Prof. Bustami Abdul Gani dan Prof. Muchtar Yahya di Indonesia. Al-Maragi juga aktif mengajar di Ma'had Tarbiyah Mu'alimat beberapa tahun sampai mendapatkan penghargaan dari Raja Mesir. Beliau masih diberikan kepercayaan sebagai direktur Madrasah Usman Mahir Basya di Kairo hingga menjelang akhir hayatnya. Pada tanggal 9 Juli 1952 M/ 1371 H, beliau menghembuskan nafas terakhirnya di Hilwan dalam usia 69 tahun. Jenazahnya dimakamkan dipemakaman keluarganya kota Kairo Mesir.

Adapun karya-karya Ahmad Musthafa al-Maragi: Muqaddimab atTafsir, Tafsir al-Maragi, Al-Hisbah fi al-Islam, Ulum al-Balagah, Al-Wajiz fi Usul al-Figh, Ad-Diyanah wa al-Akblaq, Buhuts wa Ara' fi Funun al-Balagah, Tafsir Juz. Innama as-Sabil, Al-Majaz fi 'Ulum al-Qur'an, Risalah fi Musthalah al-Hadits, Syarb Tsalatsin Haditsan, Tarikh 'Ulum al-Balagah wa Ta'rif bi Rijaliba, Al-Majaz fi alAdab al-Arabi, Al-Muthala'ah al-'Arabiyyah li al-Madaris as-Sudaniyah, Al-Khuthab wa al-Khuthaba' fi ad-Daulatain al-Umawiyah wa al-'Abbasiyah, Risalah fi Zaujat anNabi Shalla Allahu'alabi wa Sallam, Risalah Itsbat Ru'yah al-Hilal fi Ramadhan, Hidayah Thullab, dan Ar-Rifg bi al-Hayawan fi al-Islam. Karya beliau sangat monumental ialah kitab Tafsir al-Maragi yang bercorak ilmiah dan budaya kemasyarakatan (al-adabi ijtima’i) (Sayadi, 2011:34).

\section{Penafsiran Konsep Jihad dalam Surah at-Taubah Pada Tafsir al- Maragi}

Dalam penelitian ini, terdapat 41 ayat membahas mengenai jihad dalam Alquran.Dan memberikan pembatasan pada satu surah, yaitu surah atTaubah di dalamnya terdapat 11 ayat. Peneliti akan memaparkan konsep jihad dalam surah at-Taubah, dan relevansi jihad masa kini pada tafsir al-Maragi. 
Rincian ayat dan surahnya adalah surah at-Taubah [9]: 16, 19,20, 24, 41, 44, 73, 79, 81, 86, 88.

\section{Penafsiran Ayat 16, tentang Jihad yang Haq}

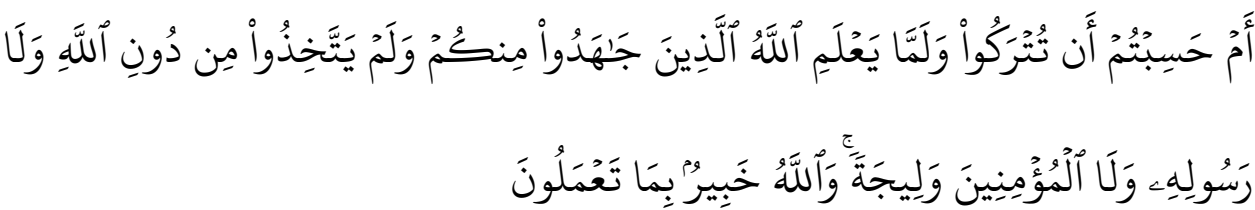

"Apakah kamu mengira bahwa kamu akan dibiarkan, sedang Allab belum mengetabui (dalam kenyataan) orang-orang yang beriihad di antara kamu dan tidak mengambil menjadi teman yang setia selain Allah, Rasul-Nya dan orangorang yang beriman. dan Allah Maha mengetahui apa yang kamu kerjakan”.

Jihad menurut tafsir al-Maragi yang diterangkan dalam ayat ini, bahwasanya: "...Dalam ayat ini membicarakan tentang keadaan kaum musimin dan perkara mereka dalam berjihad yang haq, dengan berjihad Allah membersihkan mereka dari keimanan yang lemah dan kelalaian terhadap hakhak Islam. Berjihad melawan kaum musyrikin dengan jihad jangan merasa aman bahwa mereka tidak akan kembali memerangi kalian. Menyorot pada historis bahwa mereka mengadakan perjanjian tetapi sebaliknya, mereka mengatakan bahwa mereka tidak lagi mencela agama kalian dan menghalanghalangi manusia darinya, sebagaimana telah menjadi kebiasaan mereka sejak Islam lahir? Bertebarnya dalih dusta orang-orang munafik agar tidak ikut berperang. Dan penghalangan mereka terhadap sebagiannya untuk berperang bersama kalian? Apakah kalian mengira bahwa kalian dibiarkan begitu saja tanpa ujian, sedangkan belum terdeteksi secara jelas para mujahid yang benar diantara kalian, di mana mereka tidak menjadikan teman setia dari kaum musyrikin dan munafik yang menentang Allah dan Rasulullah-Nya dengan mengahalangi manusia dari dakwanya, memerangi kaum mukmin, dan membawa orang-orangnya untuk membuka rahasia dan politik umat" (AlMaragi, 1992: 118). 
Golongan kaum Muslimin yang ada di antara mereka terdapat kaum munafik dan musyrik dalam berjihad. Jihad yang haq merupakan jihad yang bertujuan untuk menegakkan kebenaran. Dengan adanya jihad, pertama, dapat membuat umat muslim terhindar dari lemahnya iman dalam menghadapi lawannya. Kedua, adanya jihad agama Islam bisa berdiri tegak dalam menangkis lawan sehingga Allah dapat memperlihatkan kepada umat muslim lainnya bahwa tidak semua orang muslim benar-benar ikhlas tetapi mereka hanya mempunyai lebel Islam saja, dan pada dasarnya mereka pendusta yang rusak niatnya dalam menegakkan kalimat Allah. Dan bahkan Allah juga memperingatkan agar kaum Muslimin jangan mempercayai mereka secara penuh dalam hal apapun.

\section{Penafsiran Ayat 19, tentang Keutamaan Orang-Orang yang} Mengerjakan Kebajikan.

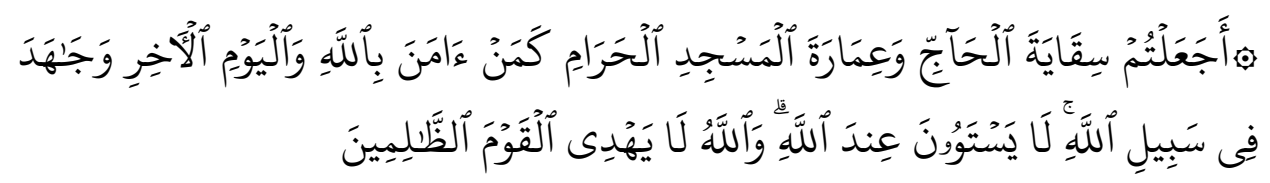

Apakah orang-orang yang memeberi minuman kepada orang-orang yang mengerjakan haji dan mengurus Masjidil Haram, kamu samakan dengan orang yang beriman kepada Allah dan hari kemudian serta berjihad di jalan Allah? Mereka tidak sama di sisi Allah. Allah tidak memberikan petunjuk kepada orang-orang zalim"

“Tidaklah sama keutamaan orang-orang yang memberi minum kepada orang-orang yang menunaikan ibadah haji,memakmurkan masjid, hari akhir dan orang yang berjihad di jalan Alllah. Meskipun memberi minum dan memakmurkan masjid termasuk kebajikan, namun para pelakunya tidak sama dengan orang yang beriman dan berjihad dalam ketinggian martabat dan kemuliaannya. Allah tidak menunjukkan kebenaran terhadap perbuatan yang mereka lakukan..." Berjihad di jalan Allah dengan diri dan harta, untuk menetapkan yang haq dan membatalkan yang batil (Al-Maragi, 1992: 131). 
Dilihat dari penafsiran di atas, ayat ini berbincang mengenai orangorang yang memberi minum pada orang yang menunaikan ibadah haji dan memakmurkan masjid dengan orang berjihad di jalan Allah SWT manakah paling utama di antara kebajikan itu.Telah dijelaskan bahwasanya semua amal yang kita lakukan pasti dibalas oleh Allah meskipun sekecil biji zarrah, dan begitu sebaliknya. Allah berikan pahala sesuai porsi amal yang kita lakukan semasa hidup kita seperti orang yang memberi minum pada orang menunaikan ibadah haji, memakmurkan masjid yakni menetap di dalamnya dan melaksanakan ibadah dalam rangka mencari ridha Allah, berzikir kepada Allah SWT, dan orang yang berjihad di jalan Allah akan diberikan pahala yang sesuai dengan pengorbanannya yaitu mereka mengorbankan harta benda maupun jiwanya untuk menegakkan agama Allah. Penafsiran disini lebih menonjolkan bahwa jihad merupakan tonggak kedua setelah Islam dan mempunyai keutamaan tersendiri.Telah kita ketahui bahwasanya betapa sulit pekerjaan berupa berjihad di jalan Allah dengan meninggalkan segala apa yang mereka cintai dalam kehidupannya bahkan diri dan jiwa mereka serahkan kepada Allah SWT. Maka dari itu berjihad merupakan suatu hal kewajiban yang memerlukan pengorbanan dan tekad serta diiringi dengan niat lillah dalam melaksanakannya.

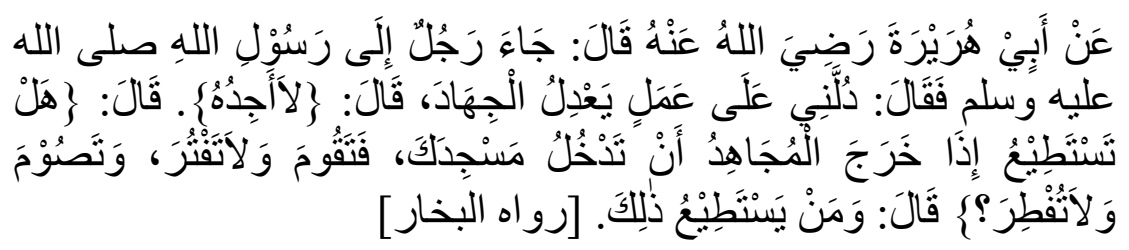

'Diriwayatkan dari Abu Hurairah r.a., dia berkata: Seorang laki-laki menghadap Rasulullah SAW kemudian berkata, "Tunjukean kepada saya amal kebaikan yang menyamai jïhad!" Rasulullah SAW bersabda,"Tidak. ada". Berikutnya Rasulullah SAW bertanya, "Ketika orang-orang pergi berjïhad, mampukah kamu masuk ke masjid untuk melaksanakan shalat tanpa henti dan berpuasa terus-menerus?" Orang itu menjawab, "Siapa yang mampu beribadah seperti itu?" (Hadis ini diriwayatkan oleh al-Bukhari, nomor hadis: 2785). 


\section{Penafsiran ayat 20, tentang Orang-orang yang Beriman, Berhijrah dan Berjihad di Jalan Allah}

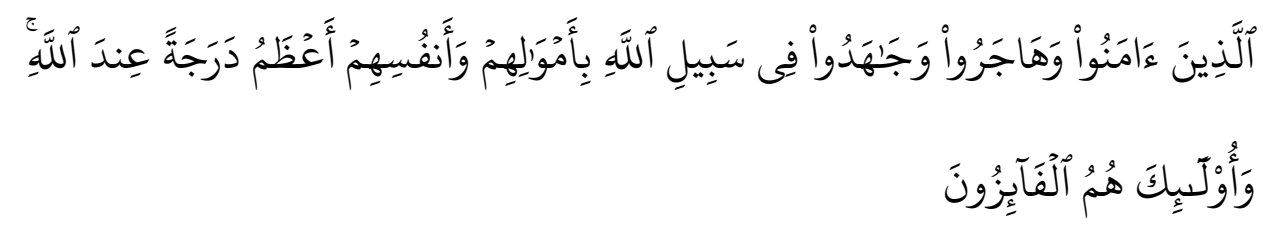

"Orang-orang yang beriman dan berbijrah serta beriihad di jalan Allah, dengan harta dan jiwa mereka, adalah lebih tinggi derajatnya di sisi Allah. Mereka itulah orang-orang yang memperoleh kemenangan"

"Orang beriman, berhijrah dan berjihad di jalan Allah dengana harta dan diri mereka, itu lebih agung derajatnya, lebih tinggi kedudukannya dalam martabat keutamaan dan kesempurnaan, dan lebih besar pahalanya dibandingkan mereka memberi minuman kepada orang yang menunaikan ibadah haji dan memakmurkan masjid, bahwa sebagian muslimin berpandangan perbuatan itu adalah jalan mendekatkan diri kepada Allah yang utama. Orang-orang yang memperoleh keutamaan hijrah dan jihad dengan diri maupun harta, lebih tinggi martabatnya dan kemuliaannya. Mukmin yang berhijrah dan berjihad ialah orang yag mendapatkan keberuntung pahala dari Allah dan kemuliaan-Nya, bukan orang-orang yang tidak mempunyai ketiga sifat ini, meskipun dia memberi minum kepada orang yang menunaikan ibadah haji dan memakmurkan Masjidil Haram. Sebab, pahala yang diberikan kepada orang mukmin didasarkan atas dua amal ini, bukan memberi minum dan memakmurkan masjid" (Al-Maragi, 1992: 132).

Allah SWT telah berjanji akan menyediakan pahala yang besar, meniggikan kedudukan mereka, dan itu hanya berlaku bagi orang beriman. Selain itu, ayat ini menjelaskan tentang keutamaan mendapatkan pahala dalam beriman, berhijrah dan berjihad. Kemudian, berdasarkan penafsiran di atas jihad juga dihubungkan dengan iman, dan dihubungkan dengan hijrah. Pertama, iman merupakan ajaran dasar agama, bahwa iman yang dapat 
membenteng seseorang dari hal-hal yang mungkar. Apabila jihad tidak dibarengi dengan iman bukanlah dikatakan jihad dikarenakan itu keluar dari konteks ajaran Islam, sedangkan orang berijihad itu harus beriman. Tetapi sebaliknya jika seseorang berjihad dibarengi dengan kerimanan dan ketakwaannya kepada Allah maka ancaman sebesar apapun mereka tidak akan pernah takut dalam menegakkan kalimatullah.Kedua, keterkaitan antara hijrah dan jihad bahwasanya hijrah merupakan fase awal dalam menghadapi orang yang ingkar kepada Allah. Karena tahap ini sangat dieratkan untuk mengumpulkan kekuatan penuh. Dan masuk pada ranah keutamaan yang dimaksudkan bahwasanya jihad dan hijrah mempunyai posisi awal yang tidak bisa dimiliki oleh setiap orang. Karena orang yang melaksanakan keduanya atau salah satunya akan mendapatkan ganjaran sesuai janji Allah.

\section{Penafsiran Ayat 24, tentang Faktor-faktor yang Merusak Jihad}

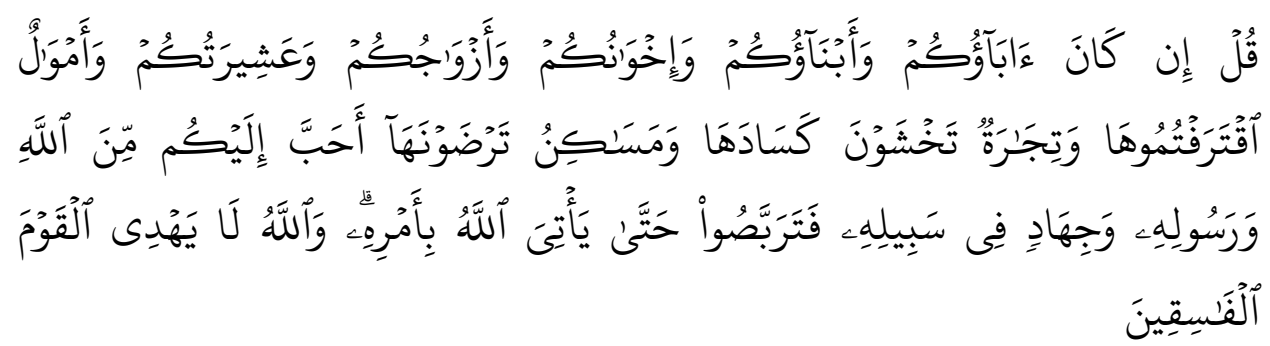

"Katakanlah, "Jika bapak-bapakmu, anak-anakmu, saudara-saudaramu, istri-istrimu, keluargamu, harta kekayaan yang kamu usahakan, perdagangan yang kamu khawatirkan kerugiannya, dan rumah-rumah tempat tinggal yang kamu sukai, lebih kamu cintai dari pada Allah dan Rasul-Nya serta berjibad di jalan-Nya, maka tunggulah sampai Allah memberikan keputusan-Nya, "Dan Allah tidak memberi petunjuk. kepada orang-orang fasik.."

Dalam menafsirakan kata jihad al-Maragi menafsirkan sebagai berikut:

“...jihad di jalan Allah yang dijanjikan, bahwa keutamaan iman, hijrah, dan jihad akan memperoleh rahmat, keridhaan-Nya, dan mendapatkan surga Allah dengan tidak menjadikan orang kafir sebagai wali, dan lebih memprioritaskan cinta kepada Allah dan Rasul serta berjihad di jalan Allah berdasarkan kecintaan kepada keluarga, kerabat, harta dan tempat tinggal...” 
“...Orang-orang fasik tidak diberikan hidayah oleh Allah yang diketahui oleh manusia dan tidak dapat diukur dengan akal sehat dan perasaan yang benar. Oleh karena itu, mereka condong mencintai kerabat dan keuntungan sementara, seperti harta dari pada Allah, Rasul-Nya, dan berjihad di jalan Allah..." (Al-Maragi, 1992: 139).

Menurut peneliti, ayat ini berbicara tentang kaitan jihad dengan kesenangan dunia. Dunia merupakan kesenangan fatamorgana yang bersifat sementar, kesenangan dunia dapat menyesatkan dan menipu manusia, dunia tempatnya ujian bagi setiap manusia dapat membuat orang terperdaya hanya sekedar permainan belaka denga mendapatkan kecapeaan dan kelalaian atas perintah-Nya. Dan janganlah kamu bergantung kepada keluarga, harta dan perniagaanmu sebab semua itu tidak dibawa ke akhirat yang adanya sebagai tanggung jawab. Dan Allah memberikan poin terpenting yaitu agar manusia menggunakan harta mereka untuk berjihad di jalan Allah SWT dan tidak mencintai semua kesenangan dunia dengan sepenuhnya. Allah akan memberikan apa yang telah dijanjikan kepada umatnya. Itulah yang ditawarkan Allah kepada kita sebagai umat yang menyembah Allah SWT.

\section{Penafsiran Ayat 41, tentang Pembagian Jihad}

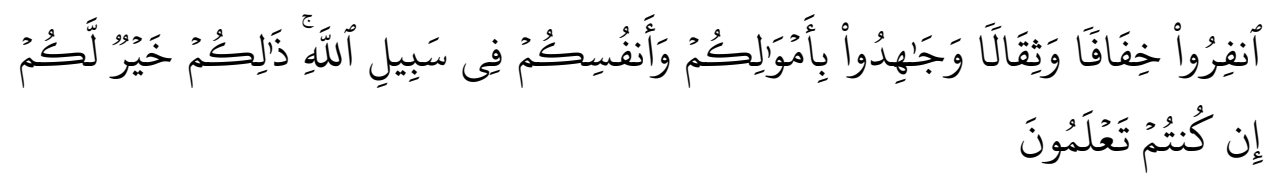

"Berangkatlah kamu baik dalam rasa ringan maupun dengan rasa berat, dan berjibadlah dengan harta dan jiwwamu di jalan allah. Yang demikian itu adalah lebih baik bagimu jikea kamu mengetabui."

“...Berangkatlah kalian dalam keadaan apapun, baik itu keadaan mudah atau susah, sehat atau sakit, kaya atau miskin, sedikitnya pembekalan atau banyak, dan lainnya. Jika perintah peperangan telah disampaikan, maka wajib ditaati terkecuali benar-benar tidak mampu untuk melaksanakannya. Allah berfirman QS. at-Taubah [9]:91. 
Pengumuman keadaan ini dikuatkan oleh perkataan Abu Ayyub alAnshari yang mengikuti seluruh peperangan, kecuali satu peperangan. Allah berfirman: infiru kbifafan wa siqalan (berangkatlah kalian untuk berjihad, baik itu keadaan ringan maupun merasa berat). Ketika itu diri saya mendapatkan kesembingan antara keduanya yakni merasa ringan dan merasa berat. Perangilah lawan kalian yang berperang di jalan tagut, merusak bumi dan kobarkanlah harta dan jiwa demi menegakkan neraca keadilan dan kalimatullah. Barang siapa yang mampu berperang dengan harta dan jiwanya sekaligus maka wajib baginya. Tetapi sebaliknya jika mampu melakukan salah satunya lakukanlah..."

Berangkat perang adalah jalan untuk memelihara keberadaan umat, menegakkan kalimat-Nya atas perintah-Nya baik itu dalam agama atau dunia, kebaikan dalam agama,hanya akan diraih bagi orang yang mempertahankan kebenaran dan keadilan sesuai ajaran agama. Sedangkan kebaikan di dunia, umat tidak memperoleh kekuasaan terkecuali melalui kekuatan perang yang merupakan jalan untuk menolak lawan. Jika kalian mengetahui pengetahuan tentang hal itu, maka berangkat dan ikutilah orang-orang beriman karena mereka telah mengetahui keutamaan itu" (Al-Maragi, 1992: 208).

Menurut peneliti, bahwa Allah SWT memerintahkan untuk berjihad baik itu dalam keadaan ringan maupun berat. Seseorang yang berjihad tidaklah semudah mengeluarkan ucapan karena berjihad harus mengorbankan dan merelakan segala apa yang dicintai di harus ditinggalkan dengan bentuk penyerahan kepada Allah. Dengan mengorbankan harta benda mereka dan jiwa mereka hanya untuk menjalankan perintah semata yaitu memerangi orang-orang ingkar kepada Allah dan memusuhi agama Allah. Itulah yang harus diperangi. Allah SWT memberikan despensasi kepada mukmin, jika di antara kalian merasa mampu untuk ikut dalam berperang maka berperanglah baik dalam keadaan ringan ataupun berat. Karena berjihad merupakan suatu kewajiban setiap umat Islam bagi yang mampu melakukannya. 


\section{Penafsiran Ayat 44, tentang Bukan Ciri Orang Mukmin Meminta Izin} Kepada Rasul Untuk Tidak Ikut Berjihad

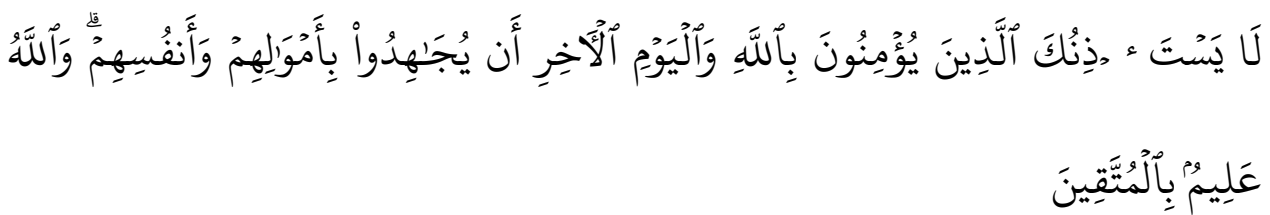

"Orang-orang yang beriman kepada Allah dan hari kemudian, tidak akan meminta ižin (tidak ikut) kepadamu untuk berijhad dengan herta dan jiwa mereka. Allah mengatehui orang-orang yang bertakwa."

"Bukan ciri orang beriman yang telah mewajibkan berperang atas mereka, dan di hari kemudian setiap amal mendapatkan ganjarannya, untuk meminta izin kepadamu (wahai Rasul) dalam masalah jihad fisabilillah dengan harta dan diri, jika keadaan menuntut mereka untuk itu. Orang beriman ialah mereka yang maju ke medan perang ketika datang kewajiban untuk itu, tanpa meminta izin”. Allah SWT berfirman: QS. al-Hujurat[49]:15.

"Bahkan mereka membuat persiapan di waktu damai, dengan mengukuhkan kekuatan dan menambat kuda. Mereka lebih utama untuk tidak meminta izin kepada Rasul mengenai perperang. Penyakit fatal yang melanda sekelompok mereka ialah perasaan berat dan berlambat-lambat, karena mereka mengira kemenangan itu sulit dicapai. Allah tahu orang-orang yang takut kepada-Nya. Orang yang bertakwa kepada Allah akan menghindari segala yang dilarang oleh-Nya dan patuh kepada perintah-Nya untuk berperang melawan musuh dengan harta dan jiwa (Al-Maragi, 1992: 126).

Orang yang meminta izin kepada Rasul bukanlah salah satu ciri dari perbuatan orang mukmin beriman. Karena orang mukmin yang beriman mereka akan melakukan apa saja yang ditetapkan oleh syari'at Islam yakni perbuatan yang ihsan dan menjauhi larangan, jika mereka mendengar jihad akan dilakukan maka bangkitlah semangat orang-orang beriman untuk berjihad. Tetapi bagi orang-orang yang meminta izin mereka tidak sedikitpun 
mempunyai rasa takzhim mereka kepada Rasulullah SAW dan mereka tidak merasa cemburu kepada saudaranya yang ikut berjihad. Perbuatan semacam itu tergolong orang munafik dan mencirikan bahwa mereka bukan termasuk orang beriman.

\section{Penafsiran Ayat 73, tentang Perlakuan Nabi SAW terhadap Kaum Munafik}

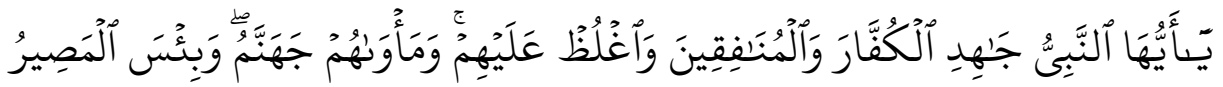

'Wahai Nabi! Berïhadlah (melawan) orang-orang kafir dan orang-orang munafik, dan bersikap keraslab terbadap mereka. Tempat mereka adalah neraka Jabannam. Dan itulah seburuk-buruk tempat kembali."

"Jihad ialah mengerahkan segenap kekuatan dan kemampuan untuk melawan musuh. Ada tiga tingkatan jihad: pertama, jihad melawan musuh yang nyata kedua, jihad melawan setan ketiga, jihad melawan hawa nafsu. Berjihad dengan lisan ialah menegakkan hujjah dan keterangan, sedangkan berjihad dengan tangan ialah dengan menggunakan pedang dan segala peralatan perang. Wahai Nabi, kerahkanlah segenap upayamu melawan orang kafir dan munafik, seperti mereka mengumpulkan kekuatannya untuk menyerangmu, dan perlakukanlah sesuai dengan apa yang mereka buat kepada umat. Ulama bersepakat, bahwa perlakukanlah kaum munafik dengan hukum syari'at, sebagaimana umat diperlakukannya. Mereka tidak boleh diperangi, terkecuali mereka murtad,memaksa kaum muslimin untuk bersikap kasar, atau tidak menegakkan syi'ar Islam. Ini merupakan jihad tersulit,sebab mereka berada di tengah antar kaum muslim yang ikhlas dengan saling megasihi dan lemah lembut, dan diharuskan bersikap keras kepada musuh yang memerangi umat.Dalam jihad ini wajib menegakkan keadilan dan menghindarkan perlakuan zalim..." Umar berkata: "Hinakanlah mereka, tetapi jangan dianiaya" (Al-Maragi, 1992: 277) 
Penafsiran menarik di sini beliau menambahkan pendapat dan ijtihad para imam mengenai ayat di atas. Objek perlawanan kaum Muslimin yaitu orang-orang kafir dan orang-orang munafik yang melampaui batas. Bahwa perlawanan ini diwajibkan jika mereka melalukan penyerangan kepada umat Islam. Tetapi sebaliknya penafsiran ini memberikan keterangan ketika berjihad dengan mereka jangan melakukan penyerangan jika mereka tidak menyerang kaum muslim.

\section{Penafsiran Ayat 79, tentang Anjuran Rasulullah SAW untuk Bersedekah dalam Perang Tabuk}

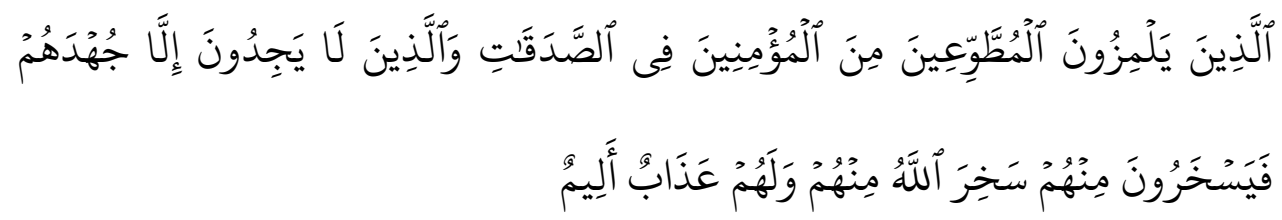

"(Orang munafik) yaitu mereka yang mencela orang-orang yang beriman dan memberikan sedekab dengan sukarela dan yang (mencela) orang-orang yang banya memperoleh (untuk disedekahkan) sekedar kesanggupannya, maka orang-orang munafik itu menghina mereka. Allah akan membelas penghinaan mereka, dan mereka akan mendapat azab yang pedib."

"Al-juhdu dan al-jabdu: kesanggupan, puncak kesanggupan manusia. Mereka mencela kaum mukminin, tentang perkara sedekah yang merupakan tanda keimanan paling tampak, kemudian mereka menghina dan berkata"Mereka tidak sedekah karena Allah, tetapi karena riya' pada manusia..."Selanjutnya mereka mencela orang fakir dikarenakan sedikit mengeluarkan sedekah, sebatas kesanggupan dan kemampuannya. Mereka menghina orang fakir dan memandang sedekah mereka itu sebuah kegilaan..." (Al-Maragi, 1992: 289).

Ayat ini mengaitkan orang yang bersedekah untuk berjihad tetapi, melihat kepada orang munafik mereka itu tidak akan pernah senang dengan orang yang melakukan kebaikan. Dikarenakan mereka mempunyai penyakit hati dalam dirinya. Salah satunya gambaran ayat ini orang-orang munafik 
mencela orang mukmin dalam mengeluarkan hartanya untuk bersedekah. Mereka menghina orang miskin dan fakir mengenai takaran sedekah tetapi mereka tak menyadari perbuatannya. Padahal mereka tahu bahwa mereka adalah umat muslim yang satu, wajib saling membantu sesamanya, terutama dalam bersedekah di jalan Allah. Orang munafik itu duplikat dari orang kafir dengan motif menghancurkan agama Islam secara perlahan dan terangterangan. Orang-orang munafik itu tidaklah sadar mereka bahwa orang yang bersedekah akan mendapatkan balasan yang berlipat ganda dari Allah SWT. Begitu sebaliknya, bagi orang yang tidak mau bersedekah maka Allah persempit rezekinya. Allah SWT berfirman QS. al-Baqarah[2]: 245).

\section{Penafsiran Ayat 81, tentang Keadaan Orang-orang yang tidak Ikut}

\section{Perang}

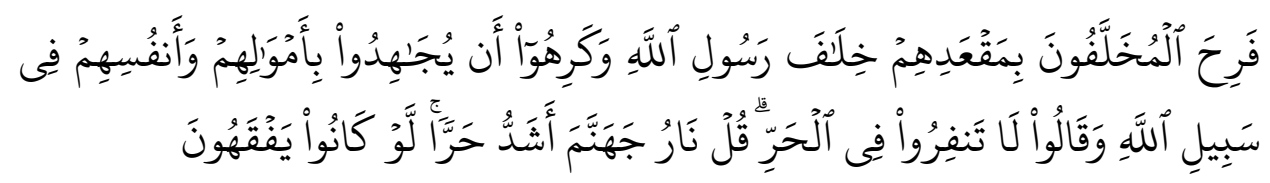

"Orang-orang yang ditinggalkan, merasa gembira dengan duduk-duduk. diam sepeninggalan Rasulullah. Meraka tidak suka berjibad dengan barta dan jüwa mereka di jalan Allah dan mereka berkata, "Janganlah kamu berangkat dalam panas terik ini. "Katakanlah(Mubammad), "Api neraka Jahannam lebih panas," jika mereka mengetahui."

"Kaum munafik yang ditinggalkan Nabi ketika perang tabuk, mereka berbahagia tetap tinggal di rumah dalam keadaan menentang Allah dan RasulNya. Mereka tidak percaya bahwa apabila ikut bersama Rasul akan mendapatkan pahala. Berkatalah mereka kepada saudaranya, "Jangan kalian keluar untuk berperang ditengah-tengan terik panas." mereka berkata demikian pada saudaranya dengan tujuan membujuk agar tetap mengikuti mereka". "Katakanlah wahai Rasul kepada mereka bahwa neraka jahannam disediakan Allah untuk orang yang durhaka kepada Allah dan Rasul-Nya, itu lebih panas. Panas neraka merupakan panas yang sangat membakar seluruh tubuh. 
Sekiranya dengan ini dapat menjadi ibrah bahwa mereka tidak tetap tinggal di rumah saja, tidak pula bergembira, tetapi sebaliknya, sebagaimana yang terjadi kepada kaum muslim ingin ikut berperang dan mengelurkan harta, namun mereka tak mampu (Al-Maragi, 1992: 295).

Menurut peneliti, ayat ini kembali menyinggung ciri orang munafik yang tidak ikut berjihad di jalan Allah, mereka sengaja ditinggalkan Rasulullah SAW untuk tidak ikut berperang, karena Rasulullah mengetahui hal itu dan mereka merasa gembira dengan menetap di rumah, mereka itulah termasuk orang yang menentang perintah Allah. Stategi mereka menghalangi kaum muslimin lainnya untuk tidak ikut berperang dalam berbagai alasan mereka membujuk dan menggoyahkan tekad umat muslim dalam berjihad. Tetapi hasutan orang munafik itu tidaklah ada apa-apanya bagi orang yang beriman kepada Allah. Allah SWT berfirman QS. al-Baqarah [2]: 157.

\section{Penafsiran Ayat 86, tentang Perintah Beriman dan Berjihad}

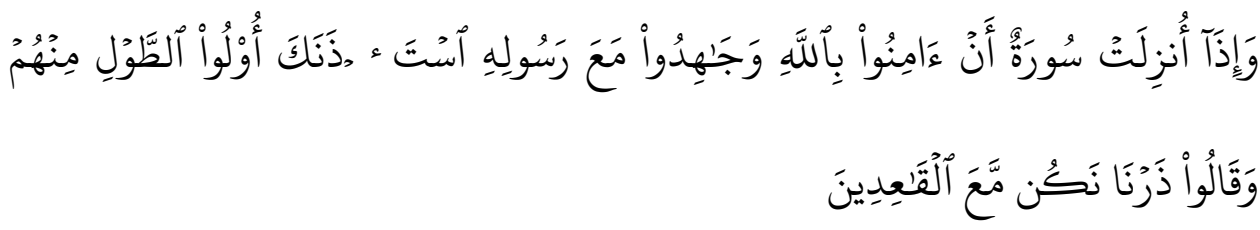

"Dan apabila diturunkan surah-surah (yang memerintabkan kepada orang-orang munafik), "Berimanlah kepada Allah dan berïhadlah bersama Rasul-Nya," niscaya orang-orang yang kaya dan berpengaruh di anatara mereka meminta izin kepadamu (untuk tidak berjibad) dan mereka berkata, "Biarkanlah kami berada bersamaorang-orang yang duduk.

"Setiap diturunkannya surah sebagian ayatnya membicarakan orang munafik untuk beriman dan berjihad bersama Rasul maka bagi orang-orang yang mempunyai kemampuan untuk berjihad dengan harta dan dirinya meminta izin kepada Rasul agar tidak ikut berperang, berkata mereka,“ Biarkan kami tinggal bersama orang-orang yang berada di rumah, seperti orang yang lemah, orang sakit yang tidak mempunyai kesanggupan utnuk berperang, anak-anak kecil, dan kaum wanita, dan mereka tidak diwajibkan 
untuk ikut berperang. Senada dengan QS. Muhammad[47]: 20 (Al-Maragi, 1992: 304).

Mereka meminta izin kepada Rasulullah untuk tidak ikut di dalam berperang. Karena mereka itu tidakah beriman dengan bersungguh-sungguh dan enggan berjihad kepada Allah SWT. Perbuatan yang mereka lakukan salah untuk dirinya dan kemaslahatan umat dengan senang hati mereka menawarkan dirinya untuk tetap tinggal di rumah padahal mereka mampu dari segi fisik dan harta. Bahkan mereka siap tinggal bersama orang-orang yang lemah.Ciri mereka hanya bermodal label Islam dan menunjukkan bahwa mereka sebenarnya adalah pengkhianat yang nyata.

\section{Penafsiran Ayat 88, tentang Keutamaan Orang yang Berjihad}

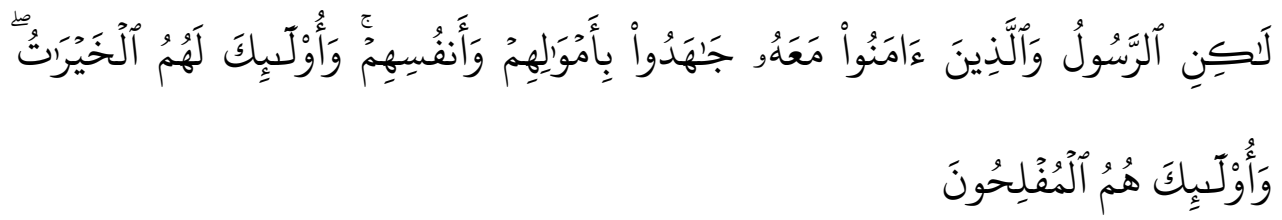

"Tetapi Rasul dan orang-orang yang beriman bersama dia, mereka berïhad dengan harta dan diri mereka. Dan mereka itulah orang-orang yang memperoleh kebaikan, dan mereka itulah orang-orang yang beruntung"

"Rasul dan orang-orang beriman selalu ikutserta dalam setiap kepentingan agama. Mereka berjihad dengan harta dan dirinya, serta melaksanakan kewajibannya sesuai dengan perintah Allah SW'T. Bagi mereka yang berjihad di jalan Allah, mereka mendapatkan kebaikan yaitu manisnya iman dan jihad merupakan kehormatan, pertolongan untuk kemusnahan atau penghapusan tanda-tanda kafir dan meninggikan kalimat Allah, menegakkan yang haq, keadilan, menikmati kesenangan di dunia, selain orang-orang munafik. Mereka yang beruntung ialah mereka yang mendapatkan kesenangan dunia dan kesenangan akhirat sedangkan diharamkan bagi orang- 
orang munafik dikarenakan kemunafikan mereka dengan harta, akhlak dan amalan mereka" (Al-Maragi, 1992: 177).

Sebagaimana yang telah disebutkan dalam Alquran QS.al-Anfal [8]: 2.Orang-orang yang beriman secara bersungguh-sungguh mereka akan mendapatkan suatu kebahagiaan di dunia maupun akhirat. Dan mereka akan diberikan tempat yang mulia di sisi Allah. Karena mereka tidak pernah mengkhianati agamanya. Serta mereka selama di dunia telah ikhlas berjihad di jalan Allah dengan harta dan jiwa mereka, mereka berjuang mati-matian mempertaruhkan jiwa raga mereka untuk Allah SW'T.

\section{Kontekstualisasi Jihad Masa Kini}

Jihad akan terus berlaku sepanjang zaman karena merupakan tonggak pembela Islam. Akan tetapi yang patut dicatat bahwa sarana dan peralatan yang digunakan untuk berjihad ialah sesuatu bersifat kondisional sehingga dapat berubah sesuai dengan zaman. Yang tidak dapat diubah ialah tujuan utama jihad, yakni memberantas kezaliman, kesewenang-wenangan, menegakkan kebenaran dan keadilan (Sayadi, 2011: 108).

Setiap zaman mempunyai masa yang berbeda-beda, Ahmad Mushafa menafsirkan ayat sesuai dengan konteks pada masa itu. Sedangkan saat ini sifat dan karakter tidak jauh berbeda pada masa Rasulullah. Pada masa itu Rasulullah menghadapi orang munafik dan orang kafir yang menentang Islam secara terang-terangan dan itu merupakan sikap yang wajar dengan cara memerangi mereka, karena dari awal peperangan yakni perang Badr sampai peperangan lainnya itu bukan bersumber dari kaum muslim yang menerbitkan amarah tetapi orang kafirlah memulai melakukan penindasan, kezaliman, dan bahkan kedengkian.

Menurut (Setiawan dan Soetapa, 2010: 60-61) dalam (Mujieb, 1994: 150-152) kafir menurut ulama fikih ialah orang yang mengingkari agama Allah atau tidak mempercayai rukun iman. Klasifikasi kafir dibagi menjadi 4: Pertama, kafir Zimmi atau abl al-Zimmah orang-orang kafir yang taat pada 
peraturan negara Islam dan berjanji akan memenuhi kewajibannya terkecuali perkara akidah. Kedua, kafir barbi orang-orang kafir yang wajib diperangi karena selalu mengganggu, mengacau, dan mengancam keselamatan umat Islam. Ketiga, kafir mu'ahad orang-orang kafir yang mengadakan perjanjian dengan umat Islam bahwa mereka tidak akan saling menyerang selama batas waktu perjanjian. Keempat, kafir musta'man orang kafir yang diberi keamanan, apabila mereka masuk ke negara Islam dengan bermaksud tidak menetap dan melakukan perjanjian keamanan. Secara umum kafir adalah dusta terhadap Allah dan Rasul-Nya, serta ajaran-ajaran yang dibawanya atau kafir ialah orang-orang yang menutup-nutupi kebenaran. Maka dapat ditarik kesimpulan dari beberapa klasifikasi kafir di atas, bahwa kafir yang dimaksud dalam kitab tafsir al-Maragi ialah kafir harbi orang-orang kafir yang wajib diperangi karena selalu mengganggu, mengacau, dan mengancam keselamatan umat Islam.

Di era yang semakin canggih, terutama di bidang teknologi. Dimulai dengan media tulisan bertujuan untuk memberantas kezaliman yang bertebaran di media sosial seperti tulisan hoax dan berita lainnya. Berjihad melalui teknologi diartikan pula dengan memberikan atau menyebarkan informasi melalui media sosial. Jihad yang perlu dikembangkan yaitu jihad berupa kecanggihan teknologi bukan jihad peperangan karena sekarang keadaan berbeda, tidak lagi seperti masa Nabi. Melirik historis dahulu sasaran jihad ialah orang-orang kafir yang menentang Islam, tetapi sekarang objek jihadnya ialah orang-orang yang membenci Islam dengan tujuan untuk menghancurkan Islam, di mana mereka memperkenalkan berbagai macam cara seperti pakaian you can see, media sosial seperti televisi, internet, facebook dan lainnya. Meskipun kita lihat dengan kaca mata positive memang dapat dikatakan untuk memudahkan segala aktivitas, tetapi lihat cara mereka meluncurkan berbagai teknologi bisa membuat umat Islam jauh dari makna Islam itu sendiri, dengan meluncurkan berbagai film yang tidak mendidik, itu bentuk pelengseran secara perlahan. Maka sangat diperlukan kemajuan dalam 
bidang teknologi, diharuskan umat muslim memegang kecanggihan teknologi karena dapat menyelamatkan umat.Oleh sebab itu, umat muslim seharusnya menyadari tentang urgensi jihad melalui teknologi dengan membentuk komunitas bidang teknologi.

Alquran mengisyaratkan jihad ilmu tentang pentingnya pendistribusian kekuatan yang efektif dan beragam kepada masyarakat dalam bidang ilmiah dan praktis, yang menurut mobilisasi kekuatan untuk melayaninya, meningkatkan kebutuhan dan merealisasikan tujuannya. Alquran surah atTaubah[9]:122 penggunaan kata nafara (pergi) yang biasa dipakai dalam jihad menunjukkan bahwa memperdalam ilmu agama termasuk salah satu bentuk jihad (Al-Qardhawi, 2011: 153). Berjihad dengan ilmu merupakan suatu perkara penting karena dengan ilmu kita dapat membrantas kebodohan yang terjadi saat ini.

Berjihad haruslah mempunyai niat yang kuat terutama keimanan yang kokoh dan kekuatan fisik demi menegakkan neraca keadilan dan kebenaran. Jihad dengan diri yaitu kekuatan total dari kemampuan dalam diri sendiri dan kemampuan berjihad ini biasa bermacam-macam seperti kemampuan untuk berjihad di bidang ilmu,sosial, ekonomi, pendidikan, kesehatan,lingkungan dan banyak jihad lainnya. Sedangkan jihad dengan harta, yakni menyumbangkan harta dalam kebaikan dan mengantarkan kepada keridhaan Allah SWT. Berjihad dengan harta dapat dikatakan berjihad di bidang ekonomi yakni berusaha untuk memperoleh rezeki yang baik untuk dirinya, keluarga dan bahkan untuk orang lain. Dengan tujuan untuk membrantas kemiskinan yang merajalela, memberantas korupsi yang merupakan salah satu penyebab krisis ekonomi bangsa dan negara. Jihad dengan harta merupakan persoalan yang berdiri sendiri dan tidak dapat digugurkan oleh jihad dengan nyawa, karena kedua jihad merupakan dua taklif (ketetapan hukum) yang setara. Masing-masing tidak dapat menggantikan posisi yang lain, kecuali bagi orang yang tidak mampu mengerjakan salah satunya, maka gugurlah 
kewajiban yang tidak disanggupinya itu, tetapi kewajiban lainnya harus tetap eksis. Sedangkan orang yang mampu mengerjakan keduanya, maka kerjakanlah secara bersamaan begitu juga sebaliknya (Takruri, 2007: 1). Dengan melakukan kebajikan inilah yang dinamakan jihad dengan memanfaatkan berbagai kemampuan yang kita miliki.

Kontekstualisasi jihad ini masih sangat relevan pada saat ini tetapi dengan cara yang berbeda dilihat dari kaca mata sejarah bahwa di zaman dahulu jihad itu harus berperang tetapi sekarang jihad itu bisa dengan berbagai macam objek seperti jihad ekonomi, jihad ilmu, jihad dengan media, jihad dengan jihad dengan diri dan lainnya.

Maka cara yang tepat untuk melawan mereka yaitu dengan cara umat Islam harus kuat disegala bidang. Jihad yang mereka lontarkan terhadap kita khususnya di Indonesia, bukan sekedar mematikan tetapi jihad yang dibutuhkan saat ini adalah jihad untuk membangun, seperti jihad harta dengan melakukan kebajikan demi membantu umat, jihad dengan diri sendiri yaitu melakukan kemampuan apapun dan lainnya. Sebagaimana pendapat Jamal al-Banna yang dikutip oleh Abd. Moqsith Ghazali, pada hari ini jihad bukan kesediaan untuk mati di jalan Allah melainkan untuk hidup di jalanNya (Mutarom, 2016: 257).

\section{PENUTUP}

Setelah melakukan pembahasan dan analisa mengenai jihad maka dapat disimpulkan bahwa: konsep yang ditawarkan tafsir al-Maragi dalam surah atTaubah ialah menggerahkan segenap kekuatan, kemampuan, dan kesanggupan untuk melawan musuh baik itu orang kafir, musyrik maupun munafik, dengan mengorbankan secara totalitas harta dan diri mereka. Dalam artian ada cara tertentu yang dipaparkan oleh Ahmad Musthafa al-Maragi tentang penafsirannya yakni usahakan dengan lisan terlebih dahulu, apabila mereka melakukan lebih dari itu maka sebaliknya jihad boleh dengan tangan. Dengan tujuan berjihad atau berjuang di jalan Allah yaitu merupakan jalan 
untuk memelihara keberadaan umat dan ketinggian kalimatnya, membersihkan mereka dari keimanan yang lemah dan kelalaian terhadap hakhak Islam, menegakkan neraca keadilan, menegakkan yang haq serta mempunyai keutamaan yang lebih agung derajatnya, kemuliaannya, tinggi kedudukannya dalam martabat keutamaan dan kesempurnaan, lebih besar pahalanya, menikmati kesenangan di dunia serta Allah menjanjikan bahwa orang berjihad akan memperoleh berbagai kebahagiaan abadi di akhirat kelak. Sedangkan kontekstualisasi jihad masa kini ialah jihad dengan media, jihad dengan ekonomi, jihad dengan ilmu dan jihad dengan diri.

\section{DAFTAR REFERENSI}

Al-Maragi, Ahmad Mustafa. (1992). Terjemah Tafsir Al-Maragi, Terj. Anwar Rasyidi dkk, judul asli, Tafsir Al-Maragi, Semarang: Karya Toha Putra Semarang.

Al- Halabi.

. (1394). Tafsir Al-Maragi, Mesir: Mustafa Al-Babi

Al-Qardhawi, Yusuf. (2011). Ringkasan Fikih Jihad, Terj. Masturi Irham dkk, judul asli, Fiqih Jihad, Jakarta: Pustaka al-Kautsar.

Almascaty, Hilmy Bakar. (2001). Panduan Jihad untuk Aktivis Gerakan Islam, Jakarta:Gema Insani Press.

Baqi, Muhammad Fuad Abdul. (1981). Mu'jam Al-Mufahras fi Zhilalil Quran, Darul Fikri.

Departemen Agama RI. (2008). Hubungan Antar-Umat Beragama (Tafsir Alquran Tematik), Jakarta: Lajnah Pentashihan Mushaf Alquran.

Imzi, Ahmad Husnul Hakim. (2013). Ensiklopedi Kitab-kitab Tafsir (Kumpulan Kitab-Kitab Tafsir dari Masa Klasik sampai Masa Kontemporer), Depok: Lingkar Studi al-Qur'an (eLSiQ).

Junaedi, Didi. (2016). Menafsir Teks, Memabami Konteks: Menelisik Akar Perbedaan Penafsiran terbadap al-Qur'an, Yogyakarta: Deepublish.

Mutarom, Ahmad. (2016). Reorientasi Makna Jihad: Sebuah Tinjauan Historis Terhadap Makna Jihad Dalam Sejarah Umat Islam, 2 (2). 
Nasution, Syahrin Harahap dan Hasan Bakti. (2009). Ensikopedia Akidah Islam, Jakarta: Kencana.

Nurkholis, M. (2007). Mutiara Shalat Berjamaah Meraib Pabala 27 Derajat, Bandung: Mizania.

Ramlan. (2016). The Concept of Jihad In Islam, Journal Of Humanities And Social Science, 21 (9).

Rohimin. (2006). Jihad Makna dan Hikmah, Penerbit Erlangga.

Sayadi, Wajidi. (2011). Metodologi Tafsir Al-Qur'an (Studi atas Metode Tafsir alMaragi), Pontianak: STAIN Pontianak Press.

Ghofur, Saiful Amin. (2013). Mozaik Mufassir Al-Qur'an dari Klasik bingga Kontemporer, Yogyakarta: Kaukaba Dikantara.

Setiawan, M. Nur Kholis dan Djaka Soetapa. (2010). Meniti Kalam Kerukunan: beberapa istilah kunci dalam Islam dan Kristen. Jakarta: Gunung Mulia dalam kerja sama dengan Dialogue Centre Program Pascasarjana UIN Sunan Kalijaga dan Pusat Studi Agama-agama Fakultas Theologia UKDW.

Simanjuntak, Shara Yosevina. (2016). Analisis Kerja Sama Bilateral Indonesia Dengan Australia dalam Penanggulangan Terorisme sebagai Kejahatan Transnasional Terorganisir, Jurnal International Relations, 2 (3).

Shihab, M. Quraish. (2007). Ensiklopedia Alquran, Jakarta: Lentera Hati, 1 (3).

Takruri, Nawwaf. (2007). Al-jihad bil Mal fi Sabilillah Dabsyatnya Jibad Harta, Terj. Asep Sobari Henri Salahuddin Al-jibad bil Mal fi Sabilillah Dahsyatnya Jihad Harta, Jakarta: Gema Insani Press. 